\title{
Why do women's fields of study pay less? \\ A test of devaluation, human capital, and gender role theory
}

Fabian Ochsenfeld

Goethe University

Institute for Sociology

Grüneburgplatz 1

60323 Frankfurt, Germany

Phone +49.69.789.36631

E-mail: ochsenfeld@ soz.uni-frankfurt.de

Post-print of

Ochsenfeld, F. (2014): Why Do Women's Fields of Study Pay Less? A Test of Devaluation, Human Capital, and Gender Role Theory. European Sociological Review 30: 536-548. doi: $\underline{10.1093 / \mathrm{esr} / \mathrm{jcu} 060}$

Acknowledgements: I thank Jan Brülle, Markus Gangl, Katharina Lutz, Elisa Szulganik and two anonymous reviewers for helpful comments on earlier versions of this paper. The HIS Graduate Panel Study data used in this paper as well as the documentation (Fabian/Minks 2006) can be obtained from the GESIS Datenarchiv für Sozialwissenschaften under the study number 4272. I thank Ms. Heidrun Schneider for generously compiling and providing aggregate data from the HIS College Eligible Panels. The author bears sole responsibility for all use of the data.

Funding: This work was supported by a research grant from the Equal Opportunities Office of Goethe University. The conclusions, opinions, and other statements in this publication are the author's and not necessarily those of the sponsoring institution. 


\title{
Why do women's fields of study pay less?
}

\section{A test of devaluation, human capital, and gender role theory}

\begin{abstract}
As men are overrepresented in lucrative fields and women disproportionately graduate from disciplines that yield low wages in the labor market, horizontal sex segregation in higher education contributes significantly to economic gender inequality. But what underlies the association between sex composition and wages in fields of study? We draw on data from the German HIS Graduate Panel Study $1997(\mathrm{~N}=4092)$ and use hierarchical linear models to adjudicate between devaluation theory and explanations based on differential sorting processes: human capital and gender role theory. The resulting evidence for both human capital and devaluation theory is scant. Consistent with gender role theory, differences in the attractiveness of fields to students with a careerist approach to higher education and the labor market in turn explain most of the association between field of studies' sex composition and wage levels. We therefore conclude that gendered patterns of self-selection which derive from men's socialization into the breadwinner role rather than valuative discrimination or rational anticipation of career interruptions underlie the association between fields' sex composition and wage levels.
\end{abstract}


Women still earn considerably lower wages than men, in large part because they work in different occupations (Petersen and Morgan, 1995). As educational expansion continues and academic disciplines assume a licensing function for occupations, sex segregation in the labor market is becoming increasingly pre-structured by segregation into fields of study ${ }^{i}$ in higher education (horizontal segregation). Since disciplines predominantly chosen by women yield lower wages in the labor market than fields men typically study, researchers have come to uniformly acknowledge the importance of horizontal sex segregation at the college level for a full understanding of the gender wage gap (Daymont and Andrisani, 1984; Kalmijn and van der Lippe, 1997; Machin and Puhani, 2003; Braakmann 2013). Precisely why it is that women's fields pay less than men's, however remains an unresolved question. That is the question we address in this article.

We test three theoretical claims that compete as an explanation of the negative correlation between fields' sex composition and wages. The devaluation hypothesis holds that certain tasks are socially and thus economically depreciated precisely because they are done mostly by women (England et al., 1988; Baron and Newman, 1990; Kilbourne et al., 1994). Devaluation theory thus asserts a negative causal effect of the proportion of females in an academic field on wages. Gender role theory runs counter to the devaluation conjecture because it suggests that culture acts on the sorting process rather than on the valuation process (Charles and Bradley, 2002; 2009). In this view, women are socialized into choosing fields of study that furnish students with more cultural than economic capital (Hakim, 2000) and fewer quantitative skills (Correll, 2001); sex composition does not, however, impact wages causally because fields that provide few economic capital and few quantitative skills should pay less for purely economic reasons (Paglin and Rufolo, 1990; van de Werfhorst, 2002). Human capital theory also suggests that the negative relationship between percentage female results from self-selection rather than devaluation (Tam, 1997). In this perspective, women rationally anticipate employment interruptions when choosing a field of study and thereby deliberately sort themselves into labor market segments where non-portable human capital is less important, albeit at the cost of having to accept lower wages (Polachek, 1981).

Because devaluation theory makes a strong causal claim, support for this conjecture presupposes a research design that controls for those field characteristics which gender role and human capital theory suggest. Gerber and Cheung (2008) note that results from earlier studies have been interpreted as evidence for devaluation without sufficient justification because it cannot be ruled out that due to unobserved variable bias they merely reflect 
spurious correlations. Our study remedies this shortcoming of earlier research in that we analyze data from the HIS Graduate Panel Study 1997 (N=4092), which allows us to measure and control for characteristics that remained unobserved in earlier studies. This puts us in a position to conduct the most rigorous test to date of the devaluation conjecture with regards to fields of study. Our results confirm Gerber and Cheung's skepticism about adopting the causal interpretation to be found in earlier studies because our evidence leads to the probability that the relationship between sex composition and pay was entirely due to unobserved variable bias: earlier studies neglected the fact that fields vary in the degree to which they provide economic or cultural capital. We find that women disproportionately selfselect into the latter, men into the former, and that this almost entirely explains the association between sex composition and wages. Based on this result, we extend Gerber and Cheung's caution against hasty causal interpretations to evidence for devaluation from fixed-effects models because we doubt that the degree to which a discipline provides cultural or economic capital should be treated as time-constant.

As teachers and educational policy makers in many countries attempt to increase girls' interest and participation in the traditionally male fields of science, technology, engineering, and mathematics (STEM), understanding what underlies the link between sex composition and wages is also policy relevant. Endeavors that foster economic gender equality by supporting girls in their choice of a more lucrative degree would be bolstered if self-selection indeed proves to be pivotal. Feminist theories tend to be more skeptical of such integrationist approaches as they expect men and society at large to react in ways that lead to a resegregative backlash and devaluation anew (Reskin and Roos, 1990). Instead, they call for labor market regulations to address valuative (and direct) discrimination which, in their view, is at the root of the economic inequalities that divide male and female professions (England, 1992).

The objective of our study is thus to examine the competing accounts for the link between wages and sex composition in college fields of study as derived from devaluation, human capital, and gender role theory. In the next section 2, we review the three theories in some more detail, derive testable hypotheses and provide a brief survey of the current state of research before describing the datasets and variables we use as well as the statistical methods we apply (section 3). In section 4 we present the empirical results from which we draw our main conclusions and develop some ideas for further research (section 5). 


\section{Theoretical explanations, empirical evidence and hypotheses}

Social scientists have made considerable efforts to understand the relation between sex ratios and wage levels, mostly with regards to occupations. We draw on their work for theoretical and empirical insights and apply them to sex segregation in college degrees. Three approaches in particular bear directly on our research question: devaluation theory, human capital theory and gender role theory.

\subsection{Valuative discrimination: sex typing}

Some scholars argue that modern market economies display processes of valuation that assign lower pay to women's work. They contend that this relationship is causal and thus persists net of other characteristics that simultaneously influence occupations' remuneration such as skill level, strenuous working conditions and labor market demand (England, 1992; Kilbourne et al., 1994; England et al., 2002). Devaluation is thought to be exerted principally through employers' and consumers' cognitive bias but also through labor market institutions such as specific job requirements. Status expectation theory argues that gender stereotypes include status beliefs that ascribe greater competence and value to male occupations (Ridgeway, 2011). Theorists stress that this type of cultural bias is distinct from statistical or taste discrimination in that it is directed at occupations' sex type, not the individual worker's gender as such. Thus, given that they work in the same occupation, men's and women's wages alike should be affected by the collectively held belief that typically female work is worth less than male work (Cejka and Eagly, 1999).

Most empirical evidence for devaluation theory comes from studies that follow a residual approach - cultural devaluation is inferred whenever a negative statistical association between percentage female and wages remains after controlling for other potential influences. England et al. (1988) and Kilbourne et al. (1994) for instance provide evidence for devaluation with designs that control for time-constant characteristics of individuals, for skill demands and working conditions, and still find the hypothesized negative association between occupations' sex ratios and wage levels. England et al. (2002) follow a similar approach and show that men and women in care provider occupations suffer a significant wage penalty net of other wage relevant characteristics. This can be interpreted as evidence for devaluation since care work culturally is closely associated with feminity in general and motherliness in particular.

Another set of studies exploits changes in occupations' sex compositions and pay levels rather than information from occupation switchers. This allows for a more explicit scrutiny of the competing claims concerning causality or correlation between sex composition 
and wages since their design conforms more closely to potential outcomes under treatment states of occupations rather than individuals, the former being the units of analysis devaluation theory refers to substantively. England et al.'s (2007) research in this vein finds only very limited support for devaluation but using a much extended time series, Levanon et al.'s (2009) in other respects similar study provides stronger support for devaluation theory.

Devaluation theory has rarely been applied to fields of study (Gerber and Cheung, 2008). The most notable exception is England et al.'s (2007) study of the academic labor market that uses fixed-effects models with fields of study as units of analysis. It revealed only limited evidence for a devaluation of fields following the feminization of their student population, the authors point out, however, that a fields' feminization generally deters students from pursuing a doctorate degree and that men eschew these fields earlier than women do, which in their view is consistent with devaluation theory.

Longitudinal studies of occupations and academic fields offer valuable insights into the temporal patterns of change and given sufficient data are clearly superior to a crosssectional approach. The data requirements, however, are high since the results from any fixedeffects design hinge on the assumption that all characteristics that simultaneously effect wages and attract or deter women are either time-constant or observed. For occupations, some studies manage better than others to limit uncontrolled heterogeneity somewhat by constructing proxies for certain time-varying characteristics. For their study of academic fields England et al. (2007) had no such substitute controls available, however. Moreover, they note that there is little temporal change in the rank order of academic fields' sex composition just as England, Allison and $\mathrm{Wu}$ (2007) point out the low variation in occupations' sex ratio over time. Pay-relevant or sex-specific characteristics then are not just unobserved - since they are likely to be altered by technological, organizational and scientific developments, they are also likely to change faster than cultural sex types which are known to change very slowly (Lueptow et al., 2001). In combination with low within-variation in sex composition, this aggravates the problem of potential bias due to unobserved time-varying confounders (Angrist and Pischke, 2009: 226).

Given that panel data with sufficiently observed potential confounders of fields' sex ratio remain unavailable, cross sectional studies of differences between academic fields or occupations continue to offer valuable insights (de Ruijter et al., 2003; Magnusson, 2009; Grönlund and Magnusson, 2013). Bobbitt-Zeher (2007) and Leuze and Strauß (2012) link horizontal sex segregation in higher education to devaluation theory with regards to the nonacademic labor market and find an association between sex composition and earnings. They 
interpret this along the lines of devaluation theory but as Gerber and Cheung (2008: 307) have pointed out, such interpretation is unjustified because their analyses lack controls for potentially relevant confounders. Leuze and Strauß (2009) partly adjusted for this weakness in a study of German graduates by controlling for two measures of fields' occupation-specificity. Nevertheless, the composition effect hypothesized by devaluation theory persists in their analysis.

Horizontal sex segregation into fields of study has been shown to be exceptionally high in Germany (Charles and Bradley, 2009), thus we are likely to find a high number of fields with either predominantly female or predominantly male student populations in our data. These conditions should facilitate the occurrence of sex typing and thus devaluation as predicted by feminist theory.

Hypothesis 1: The higher the proportion of females in a field, the lower (ceteris paribus) the wages graduates receive in the labor market.

\subsection{Specialized human capital and sex segregation}

For most human capital theorists occupational sex segregation originates from women's higher probability to experience employment interruptions due to maternity (Becker, 1985). Consistent with human capital theory's conception of education as a strictly economic investment, its proponents predict that women aim for a different mix of their human capital stock than men. They are thought to acquire relatively less of the firm- and occupationspecific sorts of human capital which are prone to erode during interruptions or when changing employers and in turn to invest relatively more in general and thus portable human capital (Polachek, 1981; Estévez-Abe, 2005). Since investment in specific human capital involves higher risks of loss, its supply is thought to be lower and returns (wages) therefore higher compared to general human capital (Tam, 1997). Returns on firm-specific skills are also thought to be higher because employers finance part of the investment in this form of human capital, which puts them in a weaker wage bargaining position vis-à-vis their employees once their costs are sunk (A. Sørensen, 2000; Polavieja, 2005).

According to this reasoning, women would disproportionately self-select into fields of study that prepare for labor market segments where non-portable human capital plays only a minor role whereas men would have a higher incentive to take degrees that are typically complemented by the acquisition of firm-specific skills in the labor market. The theory of specialized human capital thus offers an alternative explanation for the link between sex composition and wages. It assumes neither direct nor valuative forms of discrimination and thus runs counter to any feminist explanation. 
Some studies ascertain a gender gap in on-the-job training that accounts for a part of women's lower wages (Duncan and Hoffman, 1979; Olsen and Sexton, 1996) and suggest that a substantial part of the participation gap is due to prior occupational segregation (Grönlund, 2012). Others, however found that segregation by industry, occupation and firm does not mediate women's lower participation rate in on-the-job training in the way suggested by human capital theory or could not establish the hypothesized participation gap in the first place (Veum, 1996; Evertsson, 2004).

In a much debated study, Tam (1997) argued that differences in the length of specialized training rather than devaluation account for the wage gap between men's and women's occupations. This conclusion, derived from a cross-sectional analysis of CPS data, was corroborated by findings from job-level data (Tomaskovic-Devey and Skaggs, 2002). Polavieja (2008) once more showed for occupations that the degree of specialization absorbs most of what initially appears to be a sex composition effect. Leahey (2007) finds that in academia, too, male professors specialize to a higher extent than their female colleagues and achieve higher earnings partly for that reason whereas Leuze and Strauß's (2009) measures of fields' occupation-specificity can hardly account for the gender pay gap although they exert a positive influence on incomes.

German women in particular should be inclined to follow the rationale human capital theory suggests as maternity leave periods after childbirth tend to be very long in international comparison due to the strong corresponding incentives set by German family policy. Note that women in our sample chose their field of study in the early-mid 1990s, when the familialistic thrust in German family policy peaked and subsidies for paid maternity leaves were extended to periods of up to 36 months. As a consequence, employers have been shown to be more hesitant about investing in on-the-job training for women (Puhani and Sonderhof, 2011) and the motherhood wage penalty is significantly higher in Germany than in other developed countries (Gangl and Ziefle, 2009). Thus, when choosing their degree the women in our study have particularly good reasons to anticipate employment interruptions in the way human capital theory predicts and eschew labor market segments that rely more extensively on firmspecific knowledge.

Hypothesis 2: The stronger a field prepares for labor market segments where firmspecific knowledge is particularly relevant, the higher (ceteris paribus) the wages graduates receive in the labor market and women eschew fields that prepare for labor market segments where firm-specific knowledge is particularly relevant. 


\subsection{Gender roles: career orientation, mathematics and field choice}

Self-selection can also serve as a starting point for a more sociological explanation of the negative association between female representation and pay. Sociologists tend to reject the economist's analytic reduction of higher education to an investment in economic (i.e. human) capital. They claim that college education provides other resources too, such as cultural capital, and that there is considerable variation between fields of study in the sorts of resources they provide (Van de Werfhorst and Kraaykamp, 2001). Sociologists also tend to reject the idea that women rationally trade wages for desirable non-monetary characteristics of occupations (i.e. portability) when choosing their field of study when entering college, arguing instead that already during childhood (Cvencek et al., 2011) boys and girls internalize and enact socially constructed gender roles that affect their decision between degrees (Charles and Bradley, 2002; 2009). Gender roles are thought to consist of multiple dimensions, among them the breadwinner role which is typically assigned to men and inclines them to base their decision for a degree and thus professional field more heavily on the income and career prospects it promises (Hakim, 2000). Material returns are thought to be less central to women as their gender identity reflects the traditionally female role of a family's caregiver and consumer of material (nutrition) and immaterial goods (art, literature, theater, etc.) (Goldin, 2006). Consequently, women should disproportionately self-select into disciplines that supply cultural resources rather than fields which provide primarily economic resources (i.e. human capital). The latter, however, are known to be in higher labor market demand and thus to yield higher wages (Windolf, 1992; Hakim, 2000; Van de Werfhorst, 2002). This is in contrast to the argument of devaluation theory that societal demand for work done by males and females is equally high - they are thought to have comparable worth - but that their wage levels differ nevertheless (England, 1992).

As careers became more important to women's identity in the 1970s, they shifted from consumption related to investment related fields (Goldin, 2006). Women's and men's integration has, however, stagnated since the 1980s (Barone, 2011; DiPrete and Buchmann, 2013) and men continue to value extrinsic rewards more highly than women do (Beutel and Marini, 1995; Shu and Marini, 1998; Duffy and Sedlacek, 2007; Busch, 2013). The theory of gendered self-selection thus continues to offer an explanation for the negative association between the proportion of females in a field of study and the wage level (Beffy et al., 2012; Zafar, 2013). Note that it is one that involves no assumptions of direct or valuative discrimination (Paglin and Rufolo, 1990: 138) but builds on assumed gender differences concerning the importance of education's economic aspect. Feminist theorists, on the other 
hand, reject the assumption that men and women differ in this respect (Reskin and Roos, 1990: 38).

Hypothesis 3: The more a field provides economic rather than cultural resources, the higher (ceteris paribus) the wages graduates receive in the labor market and women disproportionately choose fields that provide few economic resources compared to fields men typically choose.

We can derive a similar argument from gender role theory with regards to mathematics. The cultural conceptions of gender that influence students' choices for a field of study ascribe to women lower mathematical competence (Nosek et al., 2002, Lips 2004; Cvencek et al., 2011). As a result, women flock into less 'quantitative' degrees and are underrepresented in these math-intensive fields (Correll, 2001). Simultaneously, mathematics-skill bias in technological change has created excess demand for quantitative degrees and thus a wage premium (Berger, 1988; Arcidiacono, 2004). The simultaneity of both mechanisms suggests another explanation for the correlation between sex composition and wages (Paglin and Rufolo, 1990; Mitra, 2002):

Hypothesis 4: The more a field provides quantitative skills, the higher (ceteris paribus) the wages graduates receive in the labor market and women eschew math-intensive fields compared with men.

\section{Data, measures and statistical methodology}

To empirically test the theories' predictions we draw on the HIS Graduate Panel Study 1997 which provides longitudinal data for a sample of all individuals who received their first university degree (from both Universitäten and Fachhochschulen) in Germany in the academic year 1997 (Fabian and Minks, 2006). Graduates were sampled using a stratified design and interviewed by questionnaire briefly after being awarded their degree and again in 2002. We therefore apply sampling weights as provided by HIS throughout our analyses. The survey's response rate in the first wave is $27 \%$. Panel attrition between the first and second wave was $35 \%$. This data set is particularly well suited for our purposes since it provides a detailed measure for field of study and the panel's first wave has a focus on college experience and thus offers a wealth of items to construct measures for fields' characteristics. The second panel wave focuses on labor market entry and measures pre-tax monthly income, hours worked and exceptionally detailed information on participation in on-the-job training. We limit our analysis to persons with only one job because the computation of hourly wages is unreliable for individuals with more than one job. Missing values were handled through listwise deletion which did not significantly skew our sample (table A1). 
The outcome variable in all models is individuals' logged pre-tax hourly wage five years after graduation (at the time of the second interview, in 2002) which we computed from information on hours actually worked per week and gross monthly income. The key predictor derived from devaluation theory is female type which we measure by the proportion of females in a field. Human capital theory predicts that women are underrepresented in fields where knowledge acquired in college later is typically complemented with firm-specific knowledge. Our dataset allows for a test of this claim since it includes information not only on whether a person participated in continuing training but also on who initiated the training, who paid for it and who conducted it, thus allowing us to distinguish firm-specific from other forms of training. A person was coded as received firm-specific on-the-job training if she indicated participation in training that was (1) conducted by an employee of the same firm or by external staff but within the same firm or a supplier and (2) was paid for by the employer or no costs were incurred. All other forms of further training which do not have these particular firm-specific properties were coded 0 . We use the resulting dummy as an individual control variable but most importantly to construct the field-level variable proportion of graduates who received firm-specific on-the-job training which we use to test the specialized human capital conjecture.

The HIS Graduate Panel Study (HIS Absolventenpanel) includes no measure of fields' degree of mathematization, therefore we draw this information from the pooled second waves of the HIS College Eligible Panel (HIS Studienberechtigtenpanel) 2006 (N=4963) and 2008 $(\mathrm{N}=5707)$. This is possible since all HIS surveys use the same measure for field of study. Participants in the College Eligible Panel were asked for their two favorite school subjects briefly after graduation from high school. We aggregate this information by fields of study and measure fields' math-intensity by the proportion of students in a field who indicate that math was among their favorite subjects. We thus assume that math-heavy fields disproportionately attract students who enjoyed mathematics in high school.

We construct our measure of the degree to which a field provides economic rather than other sorts of resources (such as cultural capital) following a similar rationale: We assume that fields that provide primarily economic resources disproportionately attract students with a careerist (i.e. breadwinner) disposition which we measure using the following items:

(1) "What role did labor market aspects play in the choice of your specializations?",

(2) "Looking back, wherein do you see the value of your study? - In its suitability for an occupational career", 
(3) "How strongly have you set yourself the following goals for the future? - Earning very well"

We consider these substantively valid for identifying individuals whose approach to higher education and the labor market is predominantly motivated by considerations about career prospects in the sense hypothesized by gender role theory. Items with similar wording have previously been shown to indicate differences in the degree to which fields exert a 'careerist disciplinary culture' (Windolf, 1992). All three items were drawn from the HIS Graduate Panel Study's first panel wave which was compiled soon after graduation, thus they are unlikely to be contaminated by post-hoc adaptations to labor market experiences. We created dummy variables coded 1 if an individual responded to the item 'approving' or 'strongly approving' and then generated a field-level variable being the proportion of individuals who gave an approving or strongly approving answer. The three resulting field-level variables are highly intercorrelated $(\alpha=0.91)$ which further supports our assumption that they jointly measure the same latent construct, being a field's attractiveness to students with a breadwinner approach to college and life in general. We constructed a 'breadwinner field index' which is additively composed of all three field-level variables at equal weight and has a potential range between 0 and 1 . The three dummy variables for the individual responses also enter our models as controls.

We apply a set of standard control variables, namely labor market experience (measured with monthly precision), relevant work experience during college, individual ability (measured as high school GPA in standardized metric) and employment in East Germany where wages are known to be significantly lower than in West Germany. We also control for a person's gender, but note that the gender coefficient itself is irrelevant for our hypothesis tests since all theories we test seek to explain the wage gap between predominantly male and predominantly female fields of study, not the gender wage gap on the individual level.

Since all the field-level characteristics we use are group means generated from individual-level information, they could potentially be affected by measurement error due to sampling error. Obviously, information generated for small fields is more vulnerable to sampling error because the population means are estimated from fewer cases than those of large fields. We took two measures to cope with this potential source of error. First, in order to increase sample sizes, we joined small fields together where this seemed substantively justified (for instance we merged Catholic Theology with Protestant Theology into Theology, Special Needs Pedagogy with Pedagogy, Social Sciences with Political Sciences, etc.). 
Second, we restricted the sample to fields of study with more than 20 observations. In addition, the problem is unlikely to substantially distort our results because the more reliable values from large fields bear more heavily on our results since our estimation is implicitly weighted by fields' sizes as we regress on individual wages.

The process of occupational sex segregation for college graduates can be conceived of as a process with two temporally discrete steps. Women and men first sort into different fields of study when entering college, thereby training for systematically different sets of occupations and then, in the second step, they enter systematically different occupations when they make the transition from higher education to the labor market conditional on segregation resulting from the first step (Shauman, 2009). This paper is concerned exclusively with the causes and consequences of the first of these segregative steps.

Occupational and job segregation is to a significant extent a direct outcome of preceding segregation into fields of study and, to the degree it is, mediates the effect of fields on wages. Controlling for these mediating variables would therefore severely bias our results (Angrist and Pischke, 2009: 64-68), which is why we intentionally apply no controls for occupation or job. Note that to the degree that it is wage-relevant and an outcome of prior segregation into fields of study, post-college labor market segregation is thus captured by our models but attributed to its true cause - fields of study and their characteristics. The part of wage-relevant post-college labor market segregation that occurs independently from prior segregation into fields of study in turn is reflected in $\beta_{\text {female. }}{ }^{\text {ii }}$

The dataset used in our analyses thus contains information for 4092 persons who are nested in 32 fields of study. To account for the hierarchical structure of our data and because we aim to test the effects of field-level characteristics on individual wages, we use hierarchical linear models (Raudenbush and Bryk, 2002), more specifically, intercept-asoutcome models with:

$Y_{i j}=\beta_{0 j}+\beta X_{i j}+r_{i j}$

and

$$
\begin{aligned}
\beta_{0 \mathrm{j}}= & \gamma_{00}+\gamma_{01}(\text { PROP FEMALE })+\gamma_{02}(\text { PROP SPEC HUMANCAP }) \\
& +\gamma_{03}(\text { BREADWIN INDEX })+\gamma_{04}(\text { MATH INTENSITY })+u_{0 j}
\end{aligned}
$$

Where $Y_{i j}$ is logged hourly wage for individual $i$ in field $j, X$ is a vector of controls for individual characteristics, $\mathrm{r}_{\mathrm{ij}}$ is a normally distributed error, $\beta_{0 \mathrm{j}}$ is the field-specific intercept, comprised of $\gamma_{00}$, the overall intercept, $\gamma_{01}$ to $\gamma_{04}$, the effects of our four field characteristics on $\beta_{0 \mathrm{j}}$, as well as $\mathrm{u}_{0 \mathrm{j}}$, the normally distributed field-level error. 


\section{Results}

The descriptive statistics reflect the considerable degree of horizontal sex segregation in German higher education: less than half (43.4 percent) of the graduates in our sample studied in integrated fields (where $.333<$ prop. female <.666) and half of the fields in our analysis are non-integrated disciplines where the predominantly male ones without exception fall into the STEM category and where predominantly female subjects tend to either teach high culture or prepare for professions in the social and health sector (table 1). The visual description of the data (figure 1) reveals the explanandum of this study, a negative correlation between the proportion of females in a field and the average wages degree holders earn five years after graduation. However, we also see some deviation from this general pattern, dentistry, the most lucrative of all fields being the most obvious example.

Our bivariate statistics lend some plausibility to the specialized human capital hypothesis since graduates from predominantly male fields indeed display higher than average amounts of firm-specific training (table 1, table A2) although this is true only for engineers, not for natural scientists (physics, chemistry, earth sciences). Graduates from fields that cater to the cultural and creative sectors (music/musicology, design, fine arts), where internal labor markets are less common (J. Sørensen, 2000) exhibit strikingly low participation rates but graduates from the medical fields (medical science, veterinary science, dentistry) also acquire rather little firm-specific knowledge which is not surprising either since their knowledge base is known to be highly professionalized. Women are overrepresented in each of these fields.

The breadwinner field index we constructed also varies considerably across fields with Theology and Social Work being the fields with the lowest scores (table 1). This seems plausible as we would expect students of these fields to be guided by an intrinsic rather than a 'breadwinner' motivation. The humanities and social sciences also score considerably below average. Industrial engineering, the economic sciences and computer sciences in turn seem to be the most attractive fields to students with a strong careerist attitude to higher education and life. The distribution of our breadwinner field index is consistent with gender role theory since men are clearly overrepresented in fields that score high on this dimension (table 1, table A2).

Fields greatly differ in the degree to which they attract math-affine students (table 1). Unsurprisingly, mathematics clearly ranks first in this respect followed by the engineering fields and physics. Except for mathematics itself, men are clearly overrepresented in all of these fields, as predicted by gender role theory. The descriptive results (table 1), however also lead us to suspect that our results could be charged with a degree of measurement error. The 
proxy we use seems better fit to broadly distinguish a group of math-intensive degrees from a group of math-lean fields than to measure fine differences within these groups.

An initial analysis of the variance structure of our data indicates that a considerable part of the variance in logged hourly wages $(\rho=0.217)$ is due to differences between the 32 fields of study. Moreover, horizontal sex segregation accounts for almost half of the gender wage gap in our sample. ${ }^{\text {iii }}$

[ Figure 1 and table 1 about here ]

The descriptive results from our multivariate analysis corroborate what our bivariate analyses already suggested: Predominately female fields yield considerably lower wages (table 2, M1). Net of individual characteristics, a 10 percentage point difference in proportion female is associated with (approximately) a wage differential of 2.7 percent. However, the premises for the specialized human capital explanation are also given: the degree to which disciplines prepare for labor market segments that are intensive in firm-specific on-the-jobtraining is positively correlated with high wages net of individual characteristics (M2). However, we also see that the quantitative fields in which women are clearly underrepresented indeed pay higher wages (M4) and the same is true for fields that disproportionately attract students with a 'breadwinner approach' to higher education and life in general (M3). In sum, these findings reinforce the necessity to directly test the competing theories against each other in order to adjudicate between them (Gerber and Cheung, 2008).

M5 provides this due test. It explains almost $3 / 4$ of the variance in wages between fields and our field-level variables account for virtually the entire differences in pay between 'male' and 'female' disciplines - the effect of sex composition on wages as derived from devaluation theory withers away entirely once we control for other field characteristics (table 2, table A3). The same is true for the effect of math-intensity and mostly true for the influence of specific human capital (on the field level) on pay. Only the 'breadwinner index' exerts a statistically significant effect on wages (M5). In other words, fields differ considerably in the degree to which they attract students with a 'careerist' approach to higher education and life in general (table 1), most likely because they greatly differ in whether they provide primarily economic or other resources such as a broad liberal arts education (i.e. 'Bildung' or 'cultural capital') and these differences make for differences in pay even if we control for other differences such as gender composition and math-intensity. ${ }^{\text {iv }}$ The reverse, however, is not true for sex composition: Once we take into account that fields differ in more respects than just their sex composition, we find that sex composition itself is entirely unrelated to pay. 
We tested for various alternative functional forms for proportion female, none of which altered our results. Our findings are also robust against the exclusion of self-employed or part-time workers from the sample. In sum, we consider these results strong evidence in favor of gender role theory and at odds with the predictions derived from devaluation theory and the specialized human capital conjecture.

[ Table 2 about here ]

\section{Discussion}

It is a well-established fact that college graduates with degrees in disciplines typically studied by women receive significantly lower wages in the labor market than graduates from 'male' fields. Since horizontal sex segregation in higher education is one of the main factors underlying gender inequality in the labor market, it is also one that has received considerable attention from social scientists. However, it has hitherto remained unclear why it is that women's fields of study yield lower wages. In this study, we empirically tested competing answers to this question as offered by devaluation, specialized human capital and gender role theory.

Our empirical analysis produced scant evidence for the specialized human capital theory which claims that wage differences between men's and women's professions can largely be explained by differences in the distribution of and demand for specialized human capital. Although we indeed found women to be underrepresented in fields that prepare for labor market segments where firm-specific knowledge is particularly relevant, these differences explain only a small part of the association between sex composition and wages and their effect vanishes once we control for other field level characteristics.

Feminist theorists stress the importance of valuative discrimination against disciplines with a female sex type and consequently argue that "Although the content of the field of study seems to have an important relationship with earnings inequality, the gender composition of the field appears to be much more salient." (Bobbitt-Zeher, 2007: 15) Our empirical evidence calls such claims into question: First, differences in fields' attractiveness to students with a careerist approach to college education and life exert a far stronger effect on wages than differences in fields' sex composition. Second, the effect of sex composition on wages vanishes once we control for confounders. Our findings are thus at odds with devaluation theory but consonant with sociological gender role theory which argues that men internalize a breadwinner role during adolescence to a higher degree than women which they then act upon when entering college and choosing their fields of study. Consequently, men disproportionately self-select into fields of study such as engineering which primarily provide 
economic resources and thus pay high wages, whereas women disproportionately self-select into fields like Philology and Pedagogy which are better compatible with the traditionally female identity derived from the housewife role where making money is much more peripheral than in the male breadwinner role.

We arrived at our conclusions based on evidence from cross-sectional data, and we want to emphasize that as yet it remains uncertain whether our findings can be extrapolated to understand the changing wage levels of disciplines across time. The next logical step in our view would thus be to scrutinize gender role theory with longitudinal data. In turn, our results provide an insight for longitudinal studies as they caution against hasty interpretation along the lines of devaluation theory whenever changes in fields' disciplinary culture that alter their attractiveness to breadwinners are not controlled for. In the hypothetical case where a change in the degree a field provides economic rather than cultural resources (due to scientific, technical, or organizational change or some external shock) first causes a change in sex composition and with a slightly longer lag also in wages, we would see a pattern that seems like strong support for devaluation if the initial substantive changes remain unobserved. In turn, where a change in the degree a field provides economic rather than other resources first causes a change in wages and then also in sex composition, we would be misled into an interpretation in favor of queuing theory (England, Allison and $\mathrm{Wu}, 2007$ ).

Our results, which underline the consequences and persistence of conventional gender roles, fit into the larger picture sociologists have drawn over the recent decades, arguing that women's inclusion into the labor market does not necessarily result in the convergence of gender roles but, rather to the contrary, can lead men and women to express and thereby affirm their gender identity in other spheres of life, of which education is only one example.

\section{References}

Angrist, J. D. and Pischke, J.-S. (2009). Mostly Harmless Econometrics. An Empiricist's Companion. Princeton: PUP.

Arcidiacono, P. (2004). Ability Sorting and the Returns to College Major, Journal of Econometrics, 121, 343-75.

Baranowska-Rataj, A. and Unt, M. (2012). Is it Worth Becoming an Engineer in Central and Eastern Europe? The Evidence from Poland and Estonia, European Sociological Review, 28, 717-728.

Baron, J. and Newman, A. (1990). For What It's Worth. Organizations, Occupations, and the Value of Work Done by Women and Nonwhites, American Sociological Review, 55, 155-175. 
Barone, C. (2011). Some Things Never Change. Gender Segregation in Higher Education across Eight Nations and Three Decades, Sociology of Education, 84, 157-176.

Becker, G. (1985). Human Capital, Effort, and the Sexual Division of Labor, Journal of Labor Economics, 3, 33-58.

Beffy, M., Fougère, D. and Maurel, A. (2012). Choosing the Field of Study in Postsecondary Education: Do Expected Earnings Matter?, The Review of Economics and Statistics, 94, 334-347.

Berger, M. (1988). Predicted Future Earnings and Choice of College Major, Industrial and Labor Relations Review, 41, 418-429.

Beutel, A. and Marini, M. (1995): Gender and Values, American Sociological Review, 60, 436-448.

Blau, F. and Kahn, L. (2000). Gender Differences in Pay, Journal of Economic Perspectives, $14,75-99$.

Bobbitt-Zeher, D. (2007). The Gender Income Gap and the Role of Education, Sociology of Education, 80, 1-22.

Braakmann, N. (2013). What Determines Wage Inequality among Young German University Graduates?, Journal of Economics and Statistics 233: 130-58.

Busch, A. (2013). Die Geschlechtersegregation beim Berufseinstieg - Berufswerte und ihr Erklärungsbeitrag für die geschlechtstypische Berufswahl, Berliner Journal für Soziologie 23: 145-179.

Cejka, M, and Eagly, A. (1999). Gender-Stereotypic Images of Occupations Correspond to the Sex Segregation of Employment. Personality and Social Psychology Bulletin 25: 413-23.

Charles, M. and Bradley, K. (2002). Equal but Seperate? A Cross-National Study of Sex Segregation in Higher Education, American Sociological Review, 67, 573-599.

(2009). Indulging Our Gendered Selves? Sex Segregation by Field of Study in 44 Countries, American Journal of Sociology, 114, 924-976.

Correll, S. 2001. Gender and the Career Choice Process. The Role of Biased SelfAssessments, American Journal of Sociology, 106, 1691-1730.

Cvencek, D., Meltzoff, A. and Greenwald, A. (2011). Math-Gender Stereotypes in Elementary School Children, Child Development, 82, 766-779.

Daymont, T. and Andrisani, P. (1984). Job Preferences, College Major, and the Gender Gap in Earnings, The Journal of Human Resources, 14, 408-428.

Duffy, R. and Sedlacek, W. (2007). What Is Most Important to Student's Long-Term Career Choices. Analyzing 10-Year Trends and Group Differences, Journal of Career Development, 34, 149-163.

DiPrete, T. and Buchmann, C. (2013). The Rise of Women. The Growing Gender Gap in Education and What It Means for American Schools. New York: Russell Sage Foundation.

England, P. (1992). Comparable Worth. Theories and Evidence. New York: DeGruyter.

England, P., Allison, P., Li, S., Mark, N., Thompson, J., Budig, M. and Sun, H. (2007). Why Are Some Academic Fields Tipping toward Female? The Sex Composition of U.S. Fields of Doctoral Degree Receipt 1971-2002, Sociology of Education, 80, 23-42. 
England, P., Allison, P. and Wu, Y. (2007). Does Bad Pay Cause Occupations to Feminize, Does Feminization Reduce Pay, and How Can We Tell with Longitudinal Data?, Social Science Research, 36, 1237-1356.

England, P., Budig, M. and Folbre, N. (2002). Wages of Virtue. The Relative Pay of Care Work, Social Problems, 49, 455-73.

England, P., Farkas, G., Stanek-Kilbourne, B. and Dou, T. (1988). Explaining Occupational Sex Segregation and Wages. Findings from a Model with Fixed Effects, American Sociological Review, 53, 544-558.

Estévez-Abe, M (2005). Gender Bias in Skills and Social Policies. The Varieties of Capitalism Perspective on Sex Segregation, Social Politics, 12, 180-215.

Evertsson, M. (2004). Formal on-the-Job Training. A Gender-Typed Experience and WageRelated Advantage?, European Sociological Review, 20, 79-94.

Fabian, G. and Minks, K.-H. (2006). Dokumentation des Scientific Use Files "HIS Absolventenpanel 1997, Hannover: HIS.

Gangl, M. (2001). European Patterns of Labour Market Entry. A Dichotomy of Occupationalized vs. Non-Occupationalized Systems?, European Societies, 3, 471-494.

Gangl, M. and Ziefle, A. (2009). Motherhood, Labor Force Behavior, and Women's Careers. An Empirical Assessment of the Wage Penalty for Motherhood in Britain, Germany, and the United States, Demography, 46, 341-369.

Gerber, T., and Cheung, S. (2008). Horizontal Stratification in Postsecondary Education. Forms, Explanations and Implications, Annual Review of Sociology, 34, 299-318.

Goldin, C. (2006). The Quiet Revolution That Transformed Women's Employment, Education, and Family, American Economic Review, 96, 1-22.

Grönlund, A. (2012). On-the-Job Training. A Mechanism for Segregation? Examining the Relationship between Gender, Occupation, and on-the-Job Training Investments, European Sociological Review, 28, 408-420.

Grönlund, A., and Magnusson, C. (2013). Devaluation, Crowding or Skill Specificity? Exploring the Mechanisms Behind the Lower Wages in Female Professions. Social Science Research 42, 1006-1017.

Hakim, C. (2000). Work-Lifestyle Choices in the 21st Century. Preference Theory. Oxford: OUP.

Kalmijn, M., and van der Lippe, T. (1997). Type of Schooling and Sex Differences in Earnings in the Netherlands, European Sociological Review, 13, 1-15.

Kilbourne, B., Farkas, G., Beron, K., Weir, D. and P. England (1994). Returns to Skill, Compensating Differentials, and Gender Bias. Effects of Occupational Characteristics on the Wages of White Women and Men. American Journal of Sociology, 100, 689719.

Leahey, E. (2007). Not by Productivity Alone. How Visibility and Specialization Contribute to Academic Earnings, American Sociological Review, 72, 533-561.

Leuze, K. and Strauß, S. (2009). Lohnungleichheiten zwischen Akademikerinnen und Akademikern: Der Einfluss von fachlicher Spezialisierung, frauendominierten Fächern und beruflicher Segregation, Zeitschrift für Soziologie, 38, 262-281.

(2012). Female-Typical Subjects and Their Effect on Wage Inequalities among Higher Education Graduates in Germany, European Societies, 14, 1-24. 
Levanon, A., England, P. and Allison, P. (2009). Occupational Feminization and Pay. Assessing Causal Dynamics Using 1950-2000 U.S. Census Data, Social Forces, 88, 865-892.

Lips, Hilary M. (2004). The Gender Gap in Possible Selves: Divergence of Academic SelfViews among High School and University Students, Sex Roles 50, 357-71.

Lueptow, L., Garovich-Szabo, L. and Lueptow, M. (2001). Social Change and the Persistence of Sex Typing, 1974-1997, Social Forces, 80, 1-35.

Machin, S. and Puhani, P. (2003). Subject of Degree and the Gender Wage Differential. Evidence from the UK and Germany, Economics Letters, 79, 393-400.

Magnusson, C. (2009). Gender, Occupational Prestige, and Wages: A Test of Devaluation Theory, European Sociological Review 25, 87-101.

Mitra, A. (2002). Mathematics Skill and Male-Female Wages, Journal of Socio-Economics, 31, 443-56.

Möhring, K., and Schmidt, A. (2012). Multilevel Tools, German Stata Users' Group Meetings. Berlin, 2012.

Nosek, Brian A., Banaji, M., and Greenwald, A. (2002). Math = Me, Me = Female, Therefore Math $\neq$ Me, Journal of Personality and Social Psychology 83, 44-59.

Olsen, R. and Sexton, E. (1996). Gender Differences in the Returns to and the Acquisition of on-the-Job Training, Industrial Relations, 35, 59-77.

Paglin, M. and Rufolo, A. (1990). Heterogeneous Human Capital, Occupational Choice, and Male-Female Earnings Differences, Journal of Labor Economics, 8, 123-44.

Polachek, S. (1981). Occupational Self-Selection. A Human Capital Approach to Sex Differences in Occupational Structure, The Review of Economics and Statistics, 63, 6069.

Petersen, T. and L. Morgan. (1995). Separate and Unequal. Occupation-Establishment Sex Segregation and the Gender Wage Gap, American Journal of Sociology 101: 329-65.

Polavieja, J. (2005). Task Specificity and the Gender Wage Gap. Theoretical Considerations and Empirical Analysis of the Spanish Survey on Wage Structure, European Sociological Review, 21, 165-81.

(2008). The Effect of Occupational Sex-Composition on Earnings: Job-Specialisation, Sex-Role Attitudes and the Division of Domestic Labour in Spain, European Sociological Review, 24, 199-213.

Puhani, P., and Sonderhof, K. (2011). The Effects of Parental Leave on Training for Young Women, Journal of Population Economics, 24, 731-760.

Raudenbush, S. and Bryk, A. (2002). Hierarchical Linear Models. Applications and Data Analysis Methods. Second Edition. London: Sage.

Reskin, B. and Roos, P. (1990). Job Queues, Gender Queues. Explaining Women's Inroads into Male Occupations. Philadelphia: TUP.

Ridgeway, C. (2011) Framed by Gender. How Gender Inequality Persists in the Modern World. Oxford: OUP.

de Ruijter, J., van Doorne-Huiskes, A. and Schippers, J. (2003). Size and Causes of the Occupational Gender Wage-Gap in the Netherlands, European Sociological Review, 345-60. 
Shauman, K. (2009). Are There Sex Differences in the Utilization of Educational Capital among College-Educated Workers?, Social Science Research, 38, 535-571.

Shu, X. and Marini, M. (1998). Gender-Related Change in Occupational Aspirations, Sociology of Education, 71, 43-67.

Sørensen, A. (2000). Toward a Sounder Basis for Class Analysis, American Journal of Sociology, 105, 1523-1558.

Sørensen, J. (2000). The Longitudinal Effects of Group Tenure Composition on Turnover, American Sociological Review, 65, 298-310.

Tam, T. (1997). Sex Segregation and Occupational Gender Inequality in the United States. Devaluation or Specialized Training?, American Journal of Sociology, 102, 1651-1592.

Tomaskovic-Devey, D. and Skaggs, S. (2002). Sex Segregation, Labor Process Organization, and Gender Earnings Inequality, American Journal of Sociology, 108, 102-128.

Veum, J. (1996). Gender and Race Differences in Company Training, Industrial Relations, $35,32-44$.

van de Werfhorst, H. (2002): Fields of Study, Acquired Skills and the Wage Benefit from a Matching Job, Acta Sociologica, 45, 287-303.

van de Werfhorst, H. and Kraaykamp, G. (2001). Four Field-Related Educational Resources and Their Impact on Labor, Consumption, and Sociopolitical Orientation, Sociology of Education, 74, 296-317.

Windolf, P. (1992). Fachkultur und Studienfachwahl. Ergebnisse einer Befragung von Studienanfängern, Kölner Zeitschrift für Soziologie und Sozialpsychologie, 44, 76-98.

Zafar, B. (2013). College Major Choice and the Gender Gap, The Journal of Human Resources 48: 545-595. 


\section{Tables and figures}

Table 1: Descriptive statistics for 32 fields of study.

\begin{tabular}{|c|c|c|c|c|c|c|}
\hline Field of Study & $\begin{array}{l}\text { Prop. } \\
\text { female }\end{array}$ & $\begin{array}{c}\text { Avg. } \\
\text { hourly } \\
\text { wage }(€)\end{array}$ & $\begin{array}{l}\text { Math- } \\
\text { intensity }\end{array}$ & $\begin{array}{c}\text { Breadwinner } \\
\text { index }[0 ; 1]\end{array}$ & $\begin{array}{l}\text { Prop. firm- } \\
\text { spec. } \\
\text { training }\end{array}$ & $\begin{array}{c}\text { Obs. in } \\
\text { sample } \\
(=\mathrm{N})\end{array}$ \\
\hline Electrical Engineering & .04 & 22.6 & .53 & .56 & .87 & 303 \\
\hline Mechanical Engineering & .11 & 21.8 & .56 & .55 & .81 & 470 \\
\hline Physics & .11 & 21.7 & .55 & .33 & .59 & 127 \\
\hline Computer Science & .12 & 24.8 & .46 & .59 & .84 & 165 \\
\hline Industrial Engineering & .15 & 24.5 & .47 & .69 & .84 & 123 \\
\hline Civil Engineering & .19 & 18.5 & .58 & .51 & .75 & 232 \\
\hline Chemistry & .28 & 20.3 & .28 & .45 & .66 & 105 \\
\hline $\begin{array}{l}\text { Earth Sciences, } \\
\text { Geography }\end{array}$ & .31 & 17.6 & .20 & .33 & .63 & 105 \\
\hline Agronomy & .34 & 12.3 & .21 & .44 & .58 & 34 \\
\hline Economic Sciences & .42 & 21.7 & .26 & .62 & .77 & 615 \\
\hline Dentistry & .44 & 31.6 & .29 & .51 & .40 & 24 \\
\hline Law & .47 & 18.0 & .20 & .51 & .49 & 227 \\
\hline History & .49 & 16.7 & .07 & .26 & .46 & 68 \\
\hline Landscape Planning & .49 & 13.6 & .37 & .36 & .47 & 34 \\
\hline Mathematics & .49 & 19.1 & .85 & .37 & .70 & 144 \\
\hline $\begin{array}{l}\text { Architecture, } \\
\text { Interior Design }\end{array}$ & .51 & 16.3 & .40 & .37 & .51 & 100 \\
\hline Design & .52 & 16.7 & .11 & .34 & .22 & 22 \\
\hline Theology & .54 & 13.8 & .17 & .16 & .56 & 49 \\
\hline Medical Science & .56 & 18.2 & .30 & .35 & .50 & 176 \\
\hline $\begin{array}{l}\text { Social Science, Political } \\
\text { Science }\end{array}$ & .58 & 17.9 & .08 & .26 & .56 & 87 \\
\hline Music, Musicology & .59 & 14.7 & .14 & .31 & .16 & 35 \\
\hline Psychology & .63 & 19.1 & .21 & .39 & .48 & 60 \\
\hline Biology & .65 & 16.0 & .21 & .34 & .56 & 80 \\
\hline Sports & .65 & 15.9 & .12 & .30 & .52 & 35 \\
\hline Social Work & .72 & 14.8 & .20 & .24 & .60 & 102 \\
\hline Pharmaceutics & .78 & 21.2 & .20 & .49 & .58 & 32 \\
\hline Veterinary Science & .79 & 13.3 & .25 & .31 & .46 & 72 \\
\hline $\begin{array}{l}\text { Philology (other } \\
\text { than German) }\end{array}$ & .80 & 16.5 & .09 & .29 & .50 & 129 \\
\hline German Philology & .80 & 16.4 & .07 & .29 & .52 & 147 \\
\hline $\begin{array}{l}\text { Nutrition Science, } \\
\text { Home Economics }\end{array}$ & .82 & 18.1 & .26 & .44 & .64 & 21 \\
\hline Fine Arts & .82 & 13.8 & .00 & .30 & .31 & 41 \\
\hline Pedagogy & .83 & 17.5 & .19 & .28 & .62 & 128 \\
\hline Total & .41 & 19.5 & .34 & .46 & .66 & 4092 \\
\hline
\end{tabular}

Notes: Mean values, estimated. Sources: HIS Graduate Panel Study 1997, HIS College Eligible Panels 2006, 2008. 


\begin{tabular}{|c|c|c|c|c|c|}
\hline & M1 & M2 & M3 & M4 & M5 \\
\hline \multicolumn{6}{|l|}{ Field characteristics } \\
\hline \multirow[t]{2}{*}{ Prop. Female } & -.268 & - & - & - & -.014 \\
\hline & $(.001)$ & - & - & - & $(.903)$ \\
\hline \multirow[t]{2}{*}{ Prop. firm-spec. training } & - & .439 & - & - & .142 \\
\hline & - & $(.000)$ & - & - & $(.488)$ \\
\hline \multirow[t]{2}{*}{ Breadwinner index } & - & - & .732 & - & .597 \\
\hline & - & - & $(.000)$ & - & $(.008)$ \\
\hline \multirow[t]{2}{*}{ Math-intensity } & - & - & - & .297 & .009 \\
\hline & - & - & - & $(.012)$ & $(.938)$ \\
\hline \multicolumn{6}{|l|}{ Individual characteristics } \\
\hline \multirow[t]{2}{*}{ Female $(0 / 1)$} & -.056 & -.058 & -.057 & -.058 & -.056 \\
\hline & $(.000)$ & $(.000)$ & $(.000)$ & $(.000)$ & $(.000)$ \\
\hline \multirow[t]{2}{*}{ East Germany (0/1) } & -.229 & -.228 & -.229 & -.228 & -.229 \\
\hline & $(.000)$ & $(.000)$ & $(.000)$ & $(.000)$ & $(.000)$ \\
\hline \multirow[t]{2}{*}{ Experience (months) } & .0054 & .0055 & .0054 & .0054 & .0054 \\
\hline & $(.000)$ & $(.000)$ & $(.000)$ & $(.000)$ & $(.000)$ \\
\hline \multirow[t]{2}{*}{ Experience: student job (0/1) } & .046 & .046 & .046 & .046 & .046 \\
\hline & $(.000)$ & $(.000)$ & $(.000)$ & $(.000)$ & $(.000)$ \\
\hline \multirow[t]{2}{*}{ High School GPA (z-std.) } & .010 & .010 & .010 & .010 & .010 \\
\hline & $(.109)$ & $(.097)$ & $(.104)$ & $(.113)$ & $(.104)$ \\
\hline \multirow[t]{2}{*}{$\operatorname{PhD}(0 / 1)$} & .030 & .032 & .032 & .030 & .033 \\
\hline & $(.232)$ & $(.208)$ & $(.187)$ & $(.235)$ & $(.181)$ \\
\hline \multirow[t]{2}{*}{ Firm-specific training $(0 / 1)$} & .110 & .109 & .110 & .110 & .109 \\
\hline & $(.000)$ & $(.000)$ & $(.000)$ & $(.000)$ & $(.000)$ \\
\hline \multirow[t]{2}{*}{ Goal: earning very well $(0 / 1)$} & .055 & .055 & .055 & .055 & .055 \\
\hline & $(.000)$ & $(.000)$ & $(.000)$ & $(.000)$ & $(.000)$ \\
\hline \multirow[t]{2}{*}{ Course value: career $(0 / 1)$} & .007 & .008 & .006 & .008 & .006 \\
\hline & $(.555)$ & $(.542)$ & $(.646)$ & $(.550)$ & $(.637)$ \\
\hline \multirow[t]{2}{*}{ Choice: labor market $(0 / 1)$} & .005 & .004 & .003 & .005 & .003 \\
\hline & $(.707)$ & $(.723)$ & $(.780)$ & $(.688)$ & $(.793)$ \\
\hline \multirow[t]{2}{*}{ Intercept } & 2.57 & 2.19 & 2.16 & 2.36 & 2.13 \\
\hline & $(.000)$ & $(.000)$ & $(.000)$ & $(.000)$ & $(.000)$ \\
\hline \multicolumn{6}{|l|}{ Variance components } \\
\hline \multirow[t]{2}{*}{ Field level $\left(\sigma^{2}\left(\mathrm{u}_{0 \mathrm{j}}\right)\right)$} & .015 & .014 & .011 & .017 & .010 \\
\hline & $(.000)$ & $(.000)$ & $(.000)$ & $(.000)$ & $(.000)$ \\
\hline \multirow[t]{2}{*}{ Individual level $\left(\sigma^{2}\left(\mathrm{r}_{\mathrm{ij}}\right)\right)$} & .109 & .109 & .109 & .109 & .109 \\
\hline & $(.000)$ & $(.000)$ & $(.000)$ & $(.000)$ & $(.000)$ \\
\hline \multirow{2}{*}{$\begin{array}{l}\mathrm{R}^{2} \text { (between fields) } \\
\mathrm{R}^{2} \text { (within fields) }\end{array}$} & 609 & .639 & .725 & .573 & .740 \\
\hline & .132 & .132 & .132 & .133 & .132 \\
\hline $\mathrm{N}$ & 4092 & 4092 & 4092 & 4092 & 4092 \\
\hline
\end{tabular}


Figure 1: Distribution of 32 fields of study by wage level and sex composition. ${ }^{\mathrm{v}}$

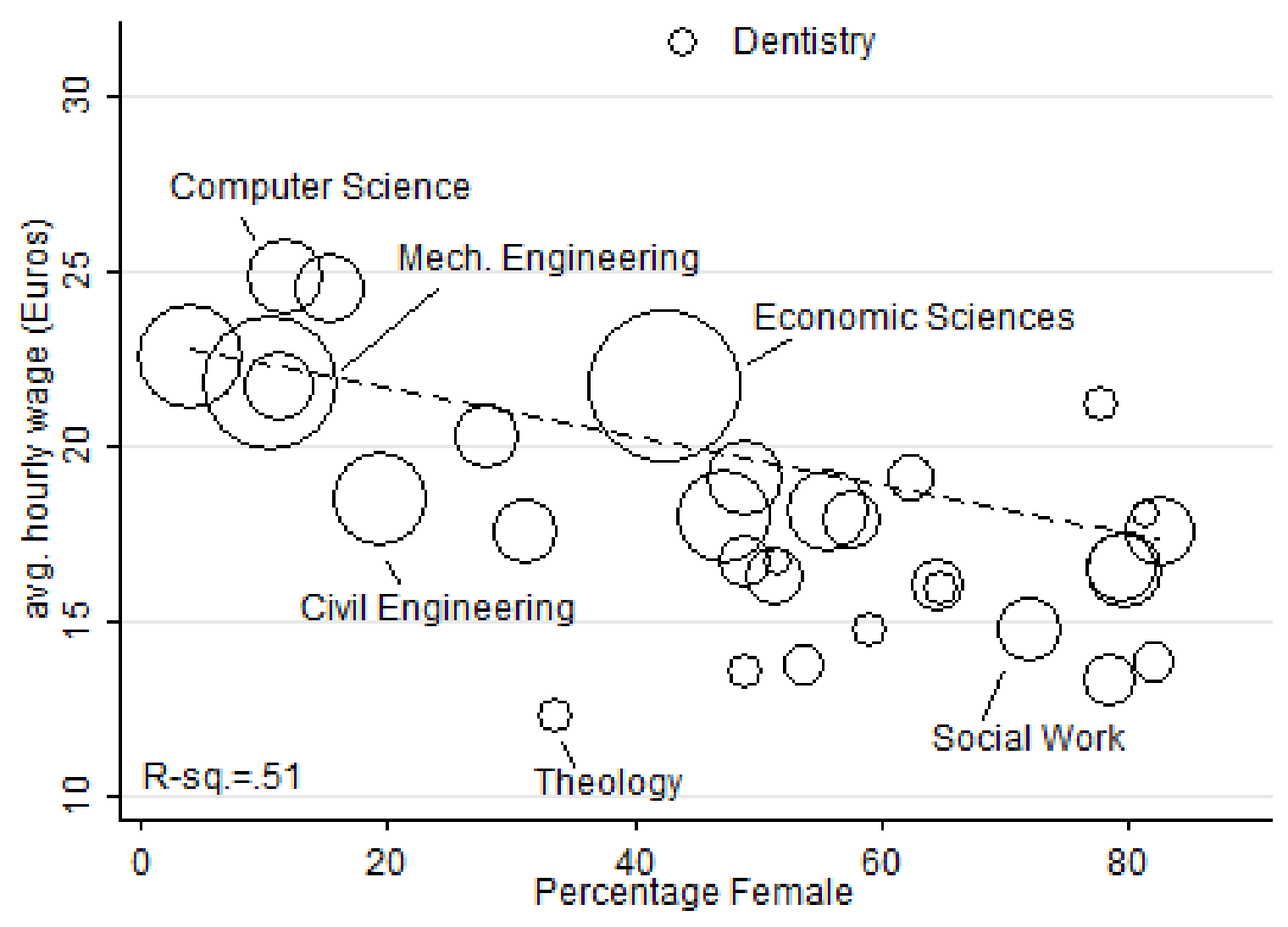




\section{Appendix / supplementary material}

Table A1: Descriptive statistics of observations in sample and observations deleted due to missing values.

\begin{tabular}{lllll}
\hline & \multicolumn{2}{c}{ Sample } & \multicolumn{2}{c}{ Deleted } \\
\hline Female (0/1) & $\bar{X}$ & s.e. & $\bar{X}$ & s.e. \\
East Germany (0/1) & .405 & .0082 & .473 & .0161 \\
Experience (months) & .13 & .0056 & .142 & .0129 \\
Experience: student job (0/1) & 59.7 & .20 & 58.8 & .43 \\
High school GPA (z-std.) & .654 & .0079 & .637 & .0156 \\
PhD (0/1) & -.003 & .0167 & .013 & .0335 \\
Firm-specific training (0/1) & .107 & .0051 & .115 & .0100 \\
Goal: earning very well (0/1) & .658 & .0080 & .648 & .0161 \\
Course value: career (0/1) & .507 & .0084 & .468 & .0170 \\
Choice: labor market (0/1) & .597 & .0082 & .601 & .0163 \\
\hline
\end{tabular}

Notes: Mean values, estimated; Source: HIS Graduate Panel Study 1997.

Table A2: Correlation matrix for field characteristics.

$\begin{array}{cccc}\text { Prop. female } & \begin{array}{c}\text { Prop. firm- } \\ \text { spec. training }\end{array} & \begin{array}{c}\text { Breadwinner } \\ \text { field index }\end{array} & \text { Math-intensity }\end{array}$

\begin{tabular}{lcccc}
\hline Prop. female [0;1] & 1 & - & - & - \\
Prop. firm-spec. training [0;1] & -.72 & 1 & - & - \\
Breadwinner index [0;1] & -.65 & .74 & 1 & - \\
Math-intensity [0;1] & -.71 & .63 & .41 & 1 \\
\hline
\end{tabular}

Notes: Correlations weighted by field size (N). Sources: HIS Graduate Panel Study 1997, HIS College Eligible Panels 2006, 2008. 


\begin{tabular}{|c|c|c|c|c|}
\hline & M1 & M6 & M7 & M5 \\
\hline \multicolumn{5}{|l|}{ Field characteristics } \\
\hline \multirow[t]{2}{*}{ Prop. Female } & -.268 & -.143 & -.017 & -.014 \\
\hline & $(.001)$ & $(.196)$ & $(.874)$ & $(.903)$ \\
\hline \multirow[t]{2}{*}{ Prop. firm-spec. training } & - & .317 & .146 & .142 \\
\hline & - & $(.055)$ & $(.438)$ & $(.488)$ \\
\hline \multirow[t]{2}{*}{ Breadwinner field index } & - & - & .597 & .597 \\
\hline & - & - & $(.008)$ & $(.008)$ \\
\hline \multirow[t]{2}{*}{ Math-intensity } & - & - & - & .009 \\
\hline & - & - & - & $(.938)$ \\
\hline \multicolumn{5}{|l|}{ Individual characteristics } \\
\hline \multirow[t]{2}{*}{ Female $(0 / 1)$} & -.056 & -.056 & -.056 & -.056 \\
\hline & $(.000)$ & $(.000)$ & $(.000)$ & $(.000)$ \\
\hline \multirow[t]{2}{*}{ East Germany (0/1) } & -.229 & -.229 & -.229 & -.229 \\
\hline & $(.000)$ & $(.000)$ & $(.000)$ & $(.000)$ \\
\hline \multirow[t]{2}{*}{ Experience (months) } & .0054 & .0055 & .0054 & .0054 \\
\hline & $(.000)$ & $(.000)$ & $(.000)$ & $(.000)$ \\
\hline \multirow[t]{2}{*}{ Experience: student job (0/1) } & .046 & .046 & .046 & .046 \\
\hline & $(.000)$ & $(.000)$ & $(.000)$ & $(.000)$ \\
\hline \multirow[t]{2}{*}{ High school GPA (z-std.) } & .010 & .010 & .010 & .010 \\
\hline & $(.109)$ & $(.102)$ & $(.103)$ & $(.104)$ \\
\hline \multirow[t]{2}{*}{$\mathrm{PhD}(0 / 1)$} & .030 & .032 & .033 & .033 \\
\hline & $(.232)$ & $(.210)$ & $(.180)$ & $(.181)$ \\
\hline \multirow[t]{2}{*}{ Firm-specific training $(0 / 1)$} & .110 & .109 & .109 & .109 \\
\hline & $(.000)$ & $(.000)$ & $(.000)$ & $(.000)$ \\
\hline \multirow[t]{2}{*}{ Goal: earning very well (0/1) } & .055 & .055 & .055 & .055 \\
\hline & $(.000)$ & $(.000)$ & $(.000)$ & $(.000)$ \\
\hline \multirow[t]{2}{*}{ Course value: career $(0 / 1)$} & .007 & .007 & .006 & .006 \\
\hline & $(.555)$ & $(.554)$ & $(.636)$ & $(.637)$ \\
\hline \multirow[t]{2}{*}{ Choice: labor market $(0 / 1)$} & .005 & .004 & .003 & .003 \\
\hline & $(.707)$ & $(.735)$ & $(.793)$ & $(.793)$ \\
\hline \multirow[t]{2}{*}{ Intercept } & 2.57 & 2.33 & 2.13 & 2.13 \\
\hline & $(.000)$ & $(.000)$ & $(.000)$ & $(.000)$ \\
\hline \multicolumn{5}{|l|}{ Variance components } \\
\hline \multirow[t]{2}{*}{ Field level $\left(\sigma^{2}\left(\mathrm{u}_{0 \mathrm{j}}\right)\right)$} & .015 & .013 & .010 & .010 \\
\hline & $(.000)$ & $(.000)$ & $(.000)$ & $(.000)$ \\
\hline \multirow[t]{2}{*}{ Individual level $\left(\sigma^{2}\left(\mathrm{r}_{\mathrm{ij}}\right)\right)$} & .109 & .109 & .109 & .109 \\
\hline & $(.000)$ & $(.000)$ & $(.000)$ & $(.000)$ \\
\hline \multirow{2}{*}{$\begin{array}{l}\mathrm{R}^{2} \text { (between fields) } \\
\mathrm{R}^{2} \text { (within fields) }\end{array}$} & .609 & .636 & .740 & .740 \\
\hline & .132 & .132 & .132 & .132 \\
\hline $\mathrm{N}$ & 4092 & 4092 & 4092 & 4092 \\
\hline
\end{tabular}


Table A4: Determinants of logged hourly wages from three nested models with random intercepts.

\begin{tabular}{|c|c|c|c|}
\hline & M8 & M1 & M9 \\
\hline \multicolumn{4}{|l|}{ Field characteristics } \\
\hline \multirow[t]{2}{*}{ Prop. female } & -.285 & -.268 & -.051 \\
\hline & $(.001)$ & $(.001)$ & $(.587)$ \\
\hline \multirow[t]{2}{*}{ Breadwinner field index } & - & - & .672 \\
\hline & - & - & $(.000)$ \\
\hline \multicolumn{4}{|l|}{ Individual characteristics } \\
\hline \multirow[t]{2}{*}{ Female $(0 / 1)$} & -.058 & -.056 & -.056 \\
\hline & $(.000)$ & $(.000)$ & $(.000)$ \\
\hline \multirow[t]{2}{*}{ East Germany $(0 / 1)$} & -.228 & -.229 & -.229 \\
\hline & $(.000)$ & $(.000)$ & $(.000)$ \\
\hline \multirow[t]{2}{*}{ Experience (months) } & .0056 & .0054 & .0054 \\
\hline & $(.000)$ & $(.000)$ & $(.000)$ \\
\hline \multirow[t]{2}{*}{ Experience: student job (0/1) } & .047 & .046 & .046 \\
\hline & $(.000)$ & $(.000)$ & $(.000)$ \\
\hline \multirow[t]{2}{*}{ High School GPA (z-std.) } & .009 & .010 & .010 \\
\hline & $(.139)$ & $(.109)$ & $(.106)$ \\
\hline \multirow[t]{2}{*}{$\mathrm{PhD}(0 / 1)$} & .031 & .030 & .032 \\
\hline & $(.210)$ & $(.232)$ & $(.190)$ \\
\hline \multirow[t]{2}{*}{ Firm-specific training $(0 / 1)$} & .112 & .110 & .110 \\
\hline & $(.000)$ & $(.000)$ & $(.000)$ \\
\hline \multirow[t]{2}{*}{ Goal: earning very well (0/1) } & - & .055 & .055 \\
\hline & - & $(.000)$ & $(.000)$ \\
\hline \multirow[t]{2}{*}{ Course value: career $(0 / 1)$} & - & .007 & .006 \\
\hline & - & $(.555)$ & $(.645)$ \\
\hline \multirow[t]{2}{*}{ Choice: labor market $(0 / 1)$} & - & .005 & .003 \\
\hline & & $(.707)$ & $(.783)$ \\
\hline \multirow[t]{2}{*}{ Intercept } & 2.60 & 2.57 & 2.20 \\
\hline & $(.000)$ & $(.000)$ & $(.000)$ \\
\hline \multicolumn{4}{|l|}{ Variance Components } \\
\hline \multirow[t]{2}{*}{ Field level $\left(\sigma^{2}\left(\mathrm{u}_{0 \mathrm{j}}\right)\right)$} & .016 & .015 & .011 \\
\hline & $(.000)$ & $(.000)$ & $(.000)$ \\
\hline \multirow[t]{2}{*}{ Individual level $\left(\sigma^{2}\left(\mathrm{r}_{\mathrm{ij}}\right)\right)$} & .109 & .109 & .109 \\
\hline & $(.000)$ & $(.000)$ & $(.000)$ \\
\hline $\mathrm{R}^{2}$ (between fields) & .576 & .609 & .729 \\
\hline $\mathrm{R}^{2}$ (within fields) & .127 & .132 & .132 \\
\hline $\mathrm{N}$ & 4092 & 4092 & 4092 \\
\hline
\end{tabular}




\section{Endnotes}

${ }^{\mathrm{i}}$ We use the terms field of study, degree, discipline, and major interchangeably.

ii The degree to which job placement is coupled with occupational certificates is known to differ significantly between countries (Gangl, 2001; Baranowska-Rataj and Unt, 2012). For that reason the individual-level coefficient $\beta_{\text {female }}$ is potentially smaller in Germany's highly occupationalized labor market than in most other institutional contexts.

${ }^{\text {iii }}$ We estimated a linear regression model including the individual level variables (as in table 2) only and a second one that in addition includes fixed effects for fields of study. The effect size for female decreases from 0.100 to -0.052 between the models, that is by 48 percent of its initial value.

iv Also note that our interpretation of the effect of the breadwinner index is genuinely contextual: it makes no difference whether a person self-selected into a field for careerist reasons or other reasons, or retrospectively values her degree for the economic resources it provides or not - as long as that person did eventually graduate from a field that many other students did choose and value for such reasons (table 2, M3). We furthermore adopt this contextual interpretation because wage differences between male and female fields are not explained by merely compositional differences between fields regarding individual motivation but indicate differences that pertain to a field as a whole (table A4).

${ }^{\mathrm{v}}$ Circle sizes correspond to field sizes $(\mathrm{N})$. 